\title{
Die kontoere van 'n weerwoord
}

J H le Roux

\section{ABSTRACT}

\section{The outline of an answer}

This article is a response to $J A$ Loader's evaluation of my book, "A story of two ways". It is argued that neither Loader nor any other scholar referred to in the book were deliberately belittled or degraded. Every Old Testament scholar mentioned in "Story" was depicted with the greatest respect and a sincere attempt was made to understand each one. Loader is therefore accused of a one-sided Loader-centric reading. To illustrate my point some important aspects with regard to "Story" are highlighted: the intention of the book, the way in which the book received its name, the problems attached to contemporary history writing, etcetera. The main part of the paper consists of an investigation into Loader's historical approach to the Old Testament.

Hierdie is dan 'n antwoord op J A Loader se interpretasie ${ }^{1}$ van my Story of two ways's. Eers iets oor die titel van hierdie artikel. My antwoord is geensins volledig nie: dit is inderdaad net die buitelyne, die raamwerk, die kontoere. Indien daar volledig op alles geantwoord moet word, sou dit veel meer bladsye verg en die leser net nog verder vermoei. Soos die skrywer van die Johannes-evangelie word dus verklaar: nog baie ander dinge kan gesê word, maar ter wille van die gesprek is net die nodige opgeteken. Daarom dan die sketsmatige repliek. Vervolgens iets oor "weerwoord". In die woordjie "antwoord" lê daar tog iets vas, finaal en afdoende. Dalk is dit met "weerwoord" anders gesteld: dit is woord op woord. 'n Woordspel wat nooit klaarkom nie; 'n laaste woord wat net nooit gespreek word nie. So sou ek graag die onderstaande wil beskou: die raamwerk, die buitelyne van 'n weerwoord wat sekerlik ook weer ander wederwoorde sal ontlok. Of daar uiteindelik ' $n$ wenner is, is irrelevant. Belangrik is dat elkeen sy eie storie sal verwoord.

Volledigheidshalwe moet vermeld word dat 'n debat van 'n paar uur tussen my en professor Loader op 1 September 1994 onder voorsitterskap van professor Eben Scheffler by die Universiteit van Suid-Afrika plaasgevind het. Dit is deur lede van die Universiteit van Suid-Afrika en die Universiteit van Pretoria se teologiese fakulteite asook 'n aantal studente en besoekers bygewoon. 'n Groot aantal kollegas het aan die gesprek deelgeneem en alles het in 'n goeie gees verloop. 
$\mathrm{Na}$ die herhaaldelike lees van die Loaderteks moet twee opmerkings eers van die hart. Eerstens, Loader se teks is skerp en fel. Tydens die eerste lees daarvan het dit my selfs laat skrik. So amper het die jir 'at Loader my oorweldig. Oor die wenslikheid van 'n debat en 'n weerwoord het ek begin twyfel. Moet Loader se teks nie maar eerder deur 'n latere geslag beoordeel word nie? Gaan die verdere gesproke en geskrewe woorde nie dalk alles vererger nie? So het ek by myself loop en dink. Tweedens, die Loaderteks dwing my teen my eie aard in. Anders gesê: Loader se Loadersentriese teks noop my tot 'n soortgelyke Lerouxsentriese teks. Ek sal moet regverdig, verduidelik, toelig en nog allerlei ander vreeslike dinge doen. Dít vind ek tog onverkwiklik en het daarom oor die wenslikheid van 'n debat of 'n weerwoord getwyfel. Hoe dit nou ook al sy, die boot is van wal gestoot en van omkeer is daar geen sprake meer nie.

DIE KLAER EN DIE KLAGTES

Met 'n stortvloed van woorde wat voortdurend herhaal word, druk Loader sy misnoë met Story uit. Wie die eintlike "slagoffers" of "lydendes" van my geskiedenis is, is aanvanklik moeilik te bepaal. Baie name word genoem, maar in werklikheid verraai elke letter van sy artikel Loader se eie onvergenoegdheid. Hy is diep verontrus oor "ons historikus" se interpretasie van hom. En die vermelding van die ander "karakters" (Deist, Prinsloo, Gemser, ens) is slegs funksioneel: hulle dien net om Loader se eie onrus en misnoë te aksentueer. My weerwoord is daarom primêr op die figuur van Loader gerig terwyl die ander vir eers buite rekening gelaat word. Voordat ons verder gaan, word die geheue verfris deur enkele kernbesware van Loader te herhaal:

a. Klaarblyklik het die titel, "A story of two ways", geweldig aanstoot gegee. Van hierdie wonderlike titel (vgl hieronder) sê Loader dan ook allerlei vreeslike dinge. Vanweë die titel is die bydraes van die verskillende Ou-Testamentici "deur die struktuur van sy inordening (ge)relegeer tot betekenisloosheid" 3 ; skep die titel die indruk van "die landsvlagvormige... vurkpad" "; kla hy dat die skrywer "vir die soveelste keer van sy tweerykeleer vertel" 5 ; dui alles daarop "dat hy daarop uit is om te probeer (om) vakgenote 'ingepas' te kry, dus dat dit sy manier van doen is" 6 . Hierdie amperse weersin in die titel vorm een van die hoofslagare van Loader se kritiek teen die boek ${ }^{7}$. 
b. Nou verwant aan bogenoemde is die pogings van "ons padbouingenieur" 8 om die ganse geskiedenis van ons Ou-Testamentiese wetenskap by hierdie vurkpad in te dwing. Behalwe die ongelooflike verenging het hierdie strakke indeling tot die weglating van sekere belangrike persone gelei. Die "twee-weë" is volgens Loader "'n keurslyf waarin alles geforseer word... Na my mening kry professor Le Roux alles slegs teen die prys van ernstige oorvereenvoudiging, veralgemening en selfs negering in sy skema ingepas... alles wat in Suid-Afrika op die gebied van die OuTestamentiese wetenskap gedoen is, moet hierin gedruk word"9.

c. Die historikus het net oog vir wat hy dink belangrik en tipies in die denke van Loader is. Herhaaldelik word beweer dat slegs dit wat my pas, gebruik is. Gevolglik is uiters selektief met die Loaderwerke omgegaan: belangrike artikels of boeke of uitsprake is geïgnoreer en net geneem wat die historikus se eie standpunt ondersteun. In die hele proses is die Loaderbeeld baie eensydig en "eendimensioneel" geskilder. Kortom: Loader het nie kleurvol genoeg uit die verf gekom nie ${ }^{10}$.

d. Loader voel veral beswaard dat ek hom "geframe" en hom op een van die vurke van hierdie pad laat loop het. Onregverdiglik het hy toe by die Prinsloogroep beland en saam met dié groep wil hy nie die pad vat nie ${ }^{11}$.

e. Loader verdink my ook van oordadige steun aan die historiese kritiek: Story is 'n "apologie vir die historiese kritiek". Dit is niks anders as 'n oratio pro historia critica nie ${ }^{12}$. Die historiese kritiek word uitermate beklemtoon: die werk is gevolglik "apologetiese propaganda" en "oorentoesiastiese propaganda". In die proses is Ferdinand Deist tot "plaaslike vaandeldraer" van die historiese kritiek verhef. Daarteenoor staan die struktuuranalise: dit word gekarikaturiseer en doelbewus in 'n negatiewe lig gestel. En die ergste van alles: Le Roux het Loader die "groot profeet" van hierdie immanente rigting gemaak ${ }^{13}$.

f. Story toon 'n gebrek aan konteksstudie. Loader noem dit "konteksverwaarlosing"; die "kontekstuele verbande" moes aangetoon gewees het $^{14}$. Die probleem is duidelik: omdat ek twee (Deist en Prinsloo) se konteks verwaarloos het, is dit sleg, maar nou het dit ook met 'n derde (Loader) gebeur.

g. Al die "spelers" in Story is te staties voorgestel: hulle word geskets "asof hulle geen ontwikkeling deurgegaan het nie" en gevolglik is hulle 
plat ${ }^{15}$. Weer eens: omdat ek twee (Deist en Prinsloo) so geskets het, is dit sleg, maar nou het ek ook 'n derde (Loader) plat gemaak.

\section{LOADER HET DIE VOLSTE REG OM TE KRITISEER}

Een saak kan nooit oorbeklemtoon word nie: Loader se reg op skerp en indringende kritiek. Hy het die volste reg gehad om met my teks (in 'n Derridaanse sin) te mors ${ }^{16}$. Daar is tog nie 'n ware of 'n verkeerde uitleg nie en daarom val die klem op die spel met tekste. 'n Leser word genooi om 'n teks kreatief te omvorm, te herskryf of te vernietig. So spelend en morsend het Loader ook met Story omgegaan. Kennelik blyk dit dat hy veel plesier daaraan gehad het. En om erkentlik te wees: die skrywer van Story kon op hierdie wyse ook enkele mankemente in sy werk ontdek wat in die toekoms van groot waarde gaan wees.

DAAR IS TOG IETS WAT HAPER

Waaraan ek my die meeste in die Loaderartikel erger is die miskenning van Story se toonaard. Hierdie werk is in 'n gees van respek geskryf. Enigeen kan tog lees met welke waardering Loader in Story beskryf is. Dit is meer as net mooi dingetjies soos Loader sou wou sê. Hy (en so ook die ander) is selfs met groot piëteit hanteer. Niemand is aan skerp kritiek onderwerp nie (juis 'n swakheid volgens sommige). Niemand is doelbewus verneder nie. Oor hulle wat uit die boek gelaat of oor wie net 'n paar sinne geskryf is, het ek vele sielewroeging gehad. Hiervan kan W S Prinsloo, my "professoregenoot" volgens Loader, asook Eben Scheffler, getuig.

Dit is jammer dat Loader hierdie kode in die teks nie eerbiedig het nie. Allerlei afbrekende dinge word in my teks ingelees - dit is sy reg, maar ek hou nie daarvan nie. Hy verdink my van spot in die negatiewe sin. Volgens Loader bevat die teks daarom ook "iets onmiskenbaar skerps" en is sommige (veral Loader) doelbewus verteken. Hierteen kan ek nie genoeg beswaar maak nie. Dit bly my wetenskapsideaal om niemand te na te kom nie. Doelbewuste afmaak van andere se standpunte of 'n verkleinering daarvan was hoegenaamd nie my intensie nie. Veel eerder strewe ek na begrip. Onder alle omstandighede wil ek die ander verstaan. Sodanige begrip word ook slegs met die uiterste moeite verkry. En dan is dit ook nooit volledig nie, dit is maar net 'n ligstippeltjie. As ek dan in my verstaan van Loader of enige iemand anders gefaal het, is ek opreg daaroor jammer. Om my egter van 'n verborge wetenskaplike agenda te verdink, is onbillik. 
Loader is dus eg in Story teleurgesteld. Uiteraard is dit vir die skrywer van Story sleg om te verneem - veral komende van 'n baie gewaardeerde geleerde. Graag sou die skrywer dit anders wou hê, maar gedane sake het nou eenmaal geen keer nie. Tog is daar iets lastigs in die kritiek wat 'n bietjie irriteer: Loader se voorskriftelikheid. Een saak moet ons tog baie duidelik stel: Story is my geskiedenis en nie dié van Loader nie. Dit is my storie waarin ek Loader 'n goeie plek (of so het ek in elke geval gemeen) gegee het; dit is my verhaal, my aksente, my interpretasie, my rekonstruksie en nog vele dinge meer. Natuurlik is dit nie bo vernietigende kritiek verhewe nie, maar niemand het die reg om voor te skryf nie. Hinderlik is daarom Loader se voortdurende inmenging in my storie deur lange selfverdedigings en 'n geboelie met alternatiewe interpretasies. Sy optrede is onwys, onchokmaties: hy moet sy plek binne my storie ken (en dit dalk aan andere oorlaat om vir hom op te kom).

Tydens bogenoemde debat het Prinsloo asook Loader gemeen dat bogenoemde punt my te gemaklik bo kritiek stel. As alle klem op my werk val, word die kritikus baie maklik hokgeslaan: hy kan nie kritiseer, wegwys of verdoem nie, want die ander se werk sluit per definisie negatiewe oordeel uit. So bedoel ek dit hoegenaamd nie. Graag verduidelik ek dan die aard van die my in die vorige paragraaf:

a. Eerstens bevestig dit dat Story vanuit my perspektief geskryf is. Dit is my weergawe van 'n stuk geskiedenis, van 'n greep Suid-Afrikaanse kerkgeskiedenis, van 'n brokkie teologiegeskiedenis wat ek persoonlik beleef het. Story is 'n persoonlike verantwoording van dit wat ek sedert 3 Maart 1971 binne die Suid-Afrikaanse Bybelwetenskappe sien gebeur het; dit is 'n verhaal wat ek jarelank jaloers gekoester het omdat (so het ek gemeen) dit net deur my so vertel kan word. Persoonlike entoesiasme is egter nog geen beskerming teen kritiek nie. Soos uit Loader se evaluasie dan ook duidelik blyk.

b. Tweedens beklemtoon dit "ons historikus" se onvermoë om sy "karakters" ten volle te begryp. Dít illustreer net weer dat enige poging tot eietydse geskiedskrywing op 'n groot gesukkel kan uitloop: jy kan nie afstand kry nie, jy kan nie ver genoeg wegstaan om ander fasette raak te sien nie, jy kan nie alles lekker in die visier kry nie. Om met Wilma Stöckenstrom te praat: dit is moeilik om te kyk, te "beraam en (te) bereken 
in 'n boekie"; dit is onmoontlik om "korrelkoel geskiedenis in glas te omsluit"17. So gesien, kan iemand so maklik ten prooi van 'n ander se historiese oordele val. En as so 'n persoon ten hemele wil skreeu, is dit te verstane. Aan die ander kant moet die historikus se frustrasie ook begryp word; moet sy radeloosheid ook gerespekteer word as hy sê: "Jammer maar ek kry jou nog nie korrelkoel in die visier nie. Jammer maar ek kan jou nog nie histories gevat kry nie".

\section{IS LOADER MISGELEES OF NET ANDERS VERSTAAN?}

Aan die einde van sy artikel beweer Loader dat ek hom "ernstig misverstaan" het ${ }^{18}$. Het ek hom mis- of dalk net anders verstaan? Ek is van laasgenoemde moontlikheid oortuig. My lees van James Alfred Loader was anders as dié waarop hy homself lees. Ek bekyk hom van 'n ander hoek, ek sien ander dinge raak en vir my is ander sake weer belangrik. Vanweë die beperktheid van ons menswees kan dit ook nie anders nie. Ons het net gemaakte beelde van mekaar. So het Loader dus 'n perspektief op homself en so werk ek met my eie gekonstrueerde Loaderbeeld. Bogenoemde is geensins 'n poging om myself van alle blaam te onthef nie. Soos Loader tereg opmerk, gaan dit om "wat hy (dit is nou ek) gedoen het"19. Graag wil ek dan my kyk op en doen met Loader kortliks toelig. Binne die storie van ons wetenskaplike verlede moes hy slegs twee funksies vervul: as die vestiger van ' $n$ bepaalde metode en as die doyen van hulle wat hier te lande met die wysheid besig is:

a. Eerstens wou ek dus sy verband met 'n bepaalde vorm van Skrifverstaan aantoon. Volgens my oortuiging was hy instrumenteel in die vestiging van hierdie benadering as 'n dominante eksegetiese metode. Van Loader se fyngevoeligheid hieroor is ek pynlik bewus en daarom is geen issue daarvan gemaak nie. Alles word in 'n raps meer as drie bladsye beskryf. Alhoewel die geskiedenis rondom die 1978-artikel ${ }^{20}$ aan my bekend is, het ek dit nie nodig geag om te vermeld nie. As historikus wou ek slegs van die artikel se enorme invloed vertel. Vele se siening van die eksegetiese proses is daardeur ingrypend gevorm. En dit is al wat ek wou sê. Niks meer nie. Loader het daarom nie die reg om my meer te laat sê as wat ek op daardie stadium vir my betoog nodig geag het nie.

Onder geen omstandighede word Loader in hierdie bladsye ook in 'n swak lig gestel nie. Ek "frame" hom nie by Prinsloo nie. Dit is net andersom: ek "frame" Prinsloo by Loader. En as daar dan 'n skelm heilige (of heilige skelm) moet wees dan is dit niemand minder as my professore- 
genoot nie. Uit die res van Story is dit tog duidelik dat hy hierdie metode oorgeneem, aangepas, verwerk, sy eie stempel daarop geplaas het en toe uiteindelik besondere sukses daarmee behaal het. Prinsloo se storie word in die res van die verhaal breedvoerig beskryf - soveel so dat Loader eintlik sat geword het daarvan.

En Loader? Hy verdwyn volledig uit die verhaal. Op bladsy twee en dertig word die laaste keer van hom gepraat. Hy maak nog wel een of twee buiginkies, maar verdwyn tot met bladsy driehonderd volledig van die toneel. Hy maak dus eers weer sy verskyning in die voorlaaste bedryf en word dan binne 'n totaal ander toneel (of konteks) geplaas. Selfs wanneer die metodestryd die "felste" word, naamlik in hoofstuk vier, is Loader heeltemal afwesig.

b. Dit bring my by die tweede saak: Loader en die studie van die wysheid. In hoofstuk ses staan die Suid-Afrikaanse metodestryd hoegenaamd nie in die sentrum nie. Geen doelbewuste poging is aangewend om Loader te "frame" of op een van die twee weë te plaas nie. Al wat "ons historikus" wou doen, was om Loader se invloed op die wysheidstudie in Suid-Afrika aan te toon en ' $n$ beskrywing van sy wysheidsdenke aan die hand van sy belangrikste werke oor Prediker, Ester en andere te gee. En soos Jan F Celliers sou gesê het: "Dis al". Kennelik was dit te min en boonop heeltemal mis. Natuurlik is daar baie meer fasette aan die Loaderbeeld verbonde, maar ek was op daardie oomblik nie daarin geïnteresseerd nie. In die verhaal van $A$ story of two ways moes hy 'n plek vul, moes hy op 'n bepaalde manier funksioneer, moes hy die storielyn op 'n sekere manier versterk.

\section{HOE HET DIE BOEK AAN SY NAAM GEKOM? (EINTLIK IS DIT ALLES BURDEN SE SKULD)}

Dit het alles op 17 Julie 1993 gebeur. Professor Jasper Burden, professor Eben Scheffler en ek was besig om Story vir die laaste keer te proeflees. Binne 'n paar dae moes die proewe drukkers toe. Tot op daardie stadium het ons al moed begin opgee om ooit 'n geskikte titel vir die boek te vind. Die beste wat ons kon kry, was Thirty years of Old Testament scholarship in South Africa. Dit was lank, lomp en sou beslis niemand tot die leesdaad aanspoor nie. Ongeveer 17:30 op daardie dag in Julie bel Burden (die redakteur van Old Testament Essays) my en sê hy het 'n titel. Hy het so pas hoofstuk vier begin lees en die volgende woorde gevind: "This chapter could also be called: 'A story of two ways'". Dít moet die naam van die 
boek word. Ek moes daaroor nadink en die volgende dag sou ons weer gesels. Die hele nag hinder die titel my: dit werk uitstekend vir hoofstuk 4 (ongeag wat Loader later sou sê), maar kan dit ook op die hele boek van toepassing gemaak word? Dalk gaan hierdie titel net meer probleme skep, maar $A$ story of two ways is darem net duisend keer beter as Thirty years of Old Testament scholarship in South Africa. Ten spyte van alle moontlike probleme besluit ek ten gunste van Burden se voorstel. Die volgende vraag dring hom toe aan ons op: "Moet die titel nie êrens verklaar word nie"? So iets was onmoontlik want alles was reeds finaal en klaar. Hierdie twee paaie moet maar ongenoemd deurgaan. Skielik dink ek aan Umberto Eco se The name of the rose ${ }^{21}$. Haar naam word nooit genoem nie en so word die misterie voortgesit. Met A story of two ways moes dieselfde gebeur: die paaie moet nie beskryf word nie en die leser moet self met 'n kreatiewe oplossing vorendag kom. Dalk is daar meerdere paaie soos sommige tydens die debat beweer het. Dalk is daar maar net twee hoofweë met 'n verskeidenheid verbindingslyne tussenin. Hoe dit ook al sy, die titel bly mooi en die vaagheid uitdagend. Toe Hans-Georg Gadamer oor 'n soortgelyke vaagheid in die titel van sy hoofwerk, Wahrheit und Methode uitgevra is, het hy net gesê: "Ambiguity is the secret to a good title... The ambiguity of the title is its key quality" 22. Dalk is iets hiervan ook waar van $A$ story of two ways.

\section{8}

\section{PLAT OF ROND, HISTORIES OF ONHISTORIES?}

In hierdie afdeling word kortliks aan drie klagtes aandag gegee: dat Loader met voorbedagte rade by die teksimmanente groep "geframe" is, sy historiese insette willens en wetens onderspeel is en sy ontwikkeling nie verdiskonteer is nie.

a. Wat die eerste beskuldiging betref, stel ek dit slegs kortliks: Emfaties word verklaar dat Loader geensins met opset op een van die twee weë geforseer is, of dat enige poging aangewend is om hom te na te kom nie. Ek volstaan met wat reeds gesê is en voeg slegs by: tot 'n groot mate het Loader homself geklassifiseer.

b. Loader beweer dat Story aan konteksverwaarlosing ly. Hierdie is 'n geldige punt en daarom die volgende verduideliking:

* Eerstens was konteksbeskrywings onmoontlik. Tot kort voor die inhandiging van Story het die reeksredakteur (denkende aan die kostes) 
'n werk van ongeveer honderd en sestig bladsye in die vooruitsig gestel. Uiteindelik het ek duskant die vierhonderd bladsye gedraai en vir konteksstudie was daar net nie plek nie.

* Tweedens, (en laat ek ook maar eerlik wees), weet ek ook nie mooi hoe om dit doen nie. Om iemand, of in hierdie geval talle mense se intellektuele kontekste te beskryf, is 'n moeilike onderneming wat kwalik uitgevoer kan word. Hoe sou 'n mens nou Loader se konteks beskryf? Waar sal 'n mens begin en waar eindig? En wie se konteks moet in en wie se konteks moet uit?

* Derdens kan ek darem verklaar dat met 'n soortgelyke poging begin is. Met behulp van Opperman ${ }^{23}$ en Kannemeyer ${ }^{24}$ is die Dertigers bestudeer. Aan die hand daarvan wou ek die algemene geestesklimaat van die twintiger- en dertigerjare van ons eeu peil. Hierna moes veral 'n studie van die verkrampte sestiger- en sewentigerjare volg. Sodoende kon die gebeure en verwikkelinge op die gebied van die Ou-Testamentiese wetenskap skerper omlyn en beskryf word. Vanweë 'n verskeidenheid redes is hierdie projek laat vaar: dit sou Story net nog omvangryker, en ook duurder gemaak het.

c. Geensins word ontken dat daar 'n besliste historiese dimensie in Loader se boeke of artikels teenwoordig is nie. Sy vroegste werke gee reeds oorvloedige getuienis hiervan. My standpunt is dat Loader se historiese insette altyd of byna altyd dieselfde patroon vertoon - veral ten opsigte van sy belangrikste werke is dit duidelik. Hierdie patroon word tot die 1990prysboek $^{25}$ volgehou. Gevolglik is dit nie vir my moontlik om Loader se groei veral ten opsigte van sy belangrikste werke te identifiseer of te beskryf nie. Hierdie standpunt sal kortliks hieronder toegelig word.

Terloops, ek word ook daarvoor verwyt dat ek Deist te staties beskryf en Prinsloo se ontwikkeling geensins aangedui het nie. Nooit was dit egter my bedoeling om die ontwikkeling (indien enige) by elkeen te identifiseer en te beskryf nie. By Deist kom daar tog iets van so 'n "groei" na vore. Veral word dit in die beskrywing van sy hermeneutiek bemerk ${ }^{26}$. Hy het ' $n$ lang denkpad geloop om uiteindelik by 'n grammaties-historiese en 'n kreatiewe lees van 'n teks te kom. Dalk is Deist se aanwending van sosiologiese insigte en paradigmas ook tekens van 'n bepaalde ontwikkeling. Ek weet nie. Miskien moet daar nog baie meer sand in Deist se uurglas loop en nog baie meer bladsye uit sy pen vloei alvorens hieroor in klare terme gepraat kan word. En wat Prinsloo betref, is daar 'n sekere 
konstantheid of konsistensie in sy werk wat belangrik is. Miskien lê sy krag juis hierin.

d. Ons begin by die gewraakte opmerking 27 dat Loader se historiese perspektiewe in Polar structures slegs bedoel is om sy reeds ingenome standpunte te bevestig en daarom 'n addendum-karakter vertoon. Loader sê dan: "Waar kry hy die indruk dat ek alleen historiese perspektiewe ter sprake bring om my reeds ingenome standpunt te bevestig?... Maar hy het die teks van Polar structures gelees om te kan sê wat hy wil pas by sy opvatting van 'two ways' en om te sorg dat sy leser my net aan één kant van die bivurkasie raakloop" 28 . Loader voel dus ongelukkig dat ek nie die "historiese dimensie" van sy werk voldoende beklemtoon het nie. Om sy standpunt te ondersteun, verwys hy dan na Otto Kaiser se waardering vir die historiese bydrae van Polar structures. Soos reeds 'n paar keer gesê, het ek vir geen oomblik Loader se historiese insette ontken nie. In al sy werke kan dit tog ook duidelik gesien word. Wat my egter interesseer, is die manier waarop Loader met die geskiedenis of dan historiese perspektiewe omgaan. Polar structures gee inderdaad ook blyke van hierdie tipiese hantering van die historiese. Ter illustrasie word op twee voorbeelde gelet:

* Tipies van Loader is dat geskiedenis altyd agter staan: dit volg altyd die gewerskaf met die teks, dit is altyd die resultaat van sy teksbemoeienis. Historiese vrae (so kry 'n mens die indruk) moet agter staan, want dit moet eers vooraf deur teksstudie opgeroep word. Geskiedenis kan nooit voor staan nie, maar moet altyd volg. Hy begin ook sy werk oor Qohelet se polêre strukture met uitsprake soos die volgende: hy verduidelik sy metode en beklemtoon die onderskeiding tussen "textimmanent and historical perspective"; duidelik word gestel "(that) diachronic work may not precede synchronic work in literary analysis"; in plaas daarvan om met 'n diakroniese studie te begin "the literary product as it is should form the point of departure"; eers moet vorm en inhoud "be analyzed in their own right and only then historical perspectives should be brought to bear on the problems that present themselves"; en asof dit nie genoeg is nie, sê hy dit weer: "As I have said... historical considerations... have to follow synchronic study" 29. Alles is sonneklaar: daar is 'n rangorde. Eers volg die immanente lees, dan volg die historiese vrae. En dan ook net daardie vrae en sake wat deur die immanente lees na die oppervlak gebring is. So verkry Loader se omgaan met die geskiedenis die karakter van 'n addendum, as iets wat agterna kom. 
* Loader se historiese perspektiewe dra gewoonlik 'n algemene en vae karakter. As daar in hoofstuk 4 en op bladsy honderd en sewentien (onthou, die boek beslaan net honderd drie en dertig bladsye) eers by "a survey of the development of wisdom" en "historical explanation" gekom word, is daar 'n opmerklike verskil met die voorafgaande hoofstukke op te merk. Anders gestel: daar is 'n kwalitatiewe verskil tussen die voorafgaande tekswerk en dit wat volg. Alle voorafgaande teksmeganika (Loader se sterkpunt) vertoon iets van oorspronklikheid en 'n outentieke wetenskaplike omgang met die teks. Van die geskiedenis van die wysheid asook die historiese verduideliking kan egter nie dieselfde gesê word nie: dit is geweldig sekondêr. Nou is dit nie meer 'n ontleding van primêre tekste nie, maar die sameflansing van 'n bepaalde konteks met behulp van sekondêre bronne. Uiteindelik is die stuk geskiedenis wat "geproduseer" word baie vaag en algemeen. Verder is die konteks ook so gemaak dat Qohelet se uniekheid duidelik kan blyk. Ek gee toe dat my kritiek dalk te skerp is. Vir Loader was dit dalk op daardie stadium van sy ondersoek voldoende historiese inligting om sy standpunt te bewys. Vir die Oue Marburger (Kaiser) het dit dalk groot plesier verskaf ${ }^{30}$. Vir my illustreer dit egter net weer die manier waarop Loader met die geskiedenis omgaan. Ek sê nie dit is verkeerd nie. So iets is verre van my. Volgens my beklemtoon dit net geskiedenis se bepaalde addendum-karakter.

e. Hierdie soort benadering is reeds in Loader se 1975-proefskrif aangekondig en deurgevoer. Weer eens moet gestel word dat baie en belangrike historiese inligting in hierdie proefskrif aangetref word. 'n Duidelike plek word egter daaraan toegeken. Die beginpunt is sinkronies: "Sinchroniese studie gaan vooraf en diachroniese studie volg - die orde is nie omkeerbaar nie". Historiese inligting "is ontsaglik belangrik", maar "die vraag daarna en die inbring daarvan moet metodies op die regte plek geskied". En dit gebeur "nadat die teks sinchronies-analities bestudeer is" 31 .

f. Vervolgens spring ons baie jare na die 1990-prysboek waarop Loader ook in sy kritiek die aandag vestig. Onthou, ons ondersoek nog steeds Loader se hantering van geskiedenis of dan historiese perspektiewe met die oog op 'n moontlike groei en ontwikkeling in sy denke. Belangrik is die beskrywing wat Loader self verskaf:

"In dié studie bied ek onder andere 'n ondersoek na histories-kritiese perspektiewe op die Pentateugverhaal wat nie pas by die beeld wat 
professor Le Roux van my skilder nie. Hoewel ek probeer aandui hoe aandag aan die struktuur van die teks ' $n$ invalspoort is na historiese ondersoek... is dit na my eie mening... duidelik dat daar ten spyte van die kontinuïteit een en ander in die kwarteeu sedert my eerste publikasie gebeur het" 32 .

Dít is nou juis my probleem met die prysboek en die bostaande woorde van Loader. Ek kan hierdie "een en ander" wat gebeur het net nie raaksien nie. Waarin is dit geleë? In woorde soos "historical critical study", "Traditionsgeschichte" en "Wirkungsgeschichte" wat in die boek voorkom? In die wye historiese tydperke wat die boek bolangs bestryk? Inderdaad handel die werk oor 'n "nuwe" tema, maar dit verteenwoordig nog steeds die tipiese benadering ten opsigte van teks en geskiedenis wat ook in Loader se ander werke voorkom. Indien daar (soos sommige die gewoonte het) beweer word dat hierdie boek so 'n duidelike breuk of verandering in die denke van Loader verteenwoordig dat ons eintlik van 'n "vroeëre Loader" en 'n "latere Loader" moet begin praat, kan ek ongelukkig nie saampstem nie. Daar is nie sprake van 'n fundamentele wetenskaps- of teksteoretiese verandering soos byvoorbeeld destyds by Wittgenstein nie. As daar verandering is, is dit bloot kosmeties. Onder die retoriek is dieselfde Loader van alle tye aan te tref.

Loader stel sy doel met die boek duidelik. Anders as diegene wat net in Sodom en Gomorra se geografie of geskiedenis geïnteresseerd is, wil Loader ' $n$ ander soort bydrae lewer. Hy is geïnteresseerd in "these traditions, their meaning, religious background and impact" 33 . Dit is so belangrik dat ek dit graag weer wil herhaal. Loader wou die SodomGomorra-tradisies bestudeer, hulle betekenis bepaal, die religieuse (en ook ander) agtergronde vasstel en die invloed of nawerking daarvan nagaan. 'n Breë historiese taak is dus gestel. Om sy doel te bereik, begin Loader by ' $n$ "logical starting point" en dit is dan die teks in sy finale gestalte. Hy omskryf dit nog verder as "the organisation of the text 'as it is', its patterns and structures" ${ }^{4}$. Dit is ook sy oogmerk om aan te toon dat hierdie hoofstukke "a cohesive narrative unit" is en dat die verskillende episodes konsentries georden is. Sy ondersoek begin "with an analysis of the structure in order to proceed to a description of meaning" 35 . Hierby wil hy nie stilstaan nie en onderskei dan ook nog a "next stage". Dít is dan 'n histories-kritiese onderneming: "we shall set ourselves the task... by complementing a study of the structure of the text with a historical approach" 36 .

Vir eers fokus ons op Loader se ondersoek van Genesis 18-19. Hy begin met ' $n$ "immanente" lesing van die teks. Weer eens blyk sy vaardig- 
heid met die teksmeganika. Voorop staan "( $\mathrm{t})$ he compositional unity of Chapters 18 and 19 (which) can be seen in an analysis of the structure of the passage" 37 . In sy ontleding van hierdie hoofstukke verneem ons die tipiese Loaderiaanse woordeskat: "the oganisation of the narrative" 38 ; "the symmetry of the narrative" 39 ; "the narrative is carefully structured" 40 ; "it carries evidence of literary sensitiveness" 41 ; "the progressive line" 42 ; "the chiastic symmetery" 43 ; "concentric structurelpattern" 44 ; "the literary function, textual function and textual function" 45 ; "the narrative techniques" 46 . Tipies van Loader se teksbenadering is die waardering vir die skrywer en sy vermoëns. Hy het inderdaad 'n besondere oog vir "the 'highly literate' abilities of the author" 47.

Daar is ook "historiese opmerkings". Loader gebruik veral drie woorde wat by leser Le Roux onmiddellike verwagtings geskep het: historiese kritiek, Traditionsgeschichte en Wirkungsgeschichte. Loader sê tog uitdruklik in sy kritiek op my Story dat hy in sy Tale histories-kritiese "perspektiewe op die Pentateugverhaal" gebied het. Ongelukkig het "ons historikus" dit nie verreken nie ${ }^{48}$. Ek is egter nie daarvan oortuig dat Loader sy voorneme uitgevoer het nie. Anders gestel: Loader het Le Roux se lesersverwagting teleurgestel. Erger nog: die skrywer van die 1990prysboek verskil nie wesenlik van sy werke van die sewentiger of tagtiger jare nie. Ek gee enkele voorbeelde hiervan:

* Om die verhouding tussen die enkelvoud en die meervoud in Genesis 18:1-16 te verklaar, worstel Loader met twee moontlikhede: die antwoord van die bronnekritiek en die moontlikheid van 'n samevloeiing van verskillende verhale. Tot sulke ingrypende historiese verklarings is Loader nie sommer bereid nie. En die rede daarvoor? Sy finaleteks-gebondenheid bepaal vooraf (en onbewustelik?) dat hy die veilige hawe van die finale teks nooit sal verlaat nie. Hy het ook vir die werk van Van Seters waardering, want dié demp die oorentoesiasitese pogings om bronne en tradisies te rekonstrueer. Sulke rekonstruksies kan net plaasvind indien dit op die getuienis in die finale teks gebou is. So 'n hipotetiese rekonstruksie kan uiteraard ook baie handig wees: "Hypothetical reconstructions can be very helpful tools"49. Maar daar is een voorwaarde: sodanige rekonstruksies mag nie plaasvind "without due regard for the sense made by the final text" 50 .

* As Loader dan tog 'n antwoord vir die enkelvoud-meervoud-probleem verstrek, is sy finaleteksparadigma deurslaggewend. Vir hom is die finale teks net te netjies gestruktureerd en vertoon dit net te duidelik 'n 
bepaalde literêre sensitiwiteit om deur die tipiese bronneteorie verklaar te kan word. Sy antwoord is daarom byna voorspelbaar: een outeur het ouer materiaal herbewerk ${ }^{51}$. Die enkelvoud-meervoud-probleem is nou eerder 'n literêre truuk en dui op die groot bekwaamheid van die skrywer. Iets soortgelyks word in verband met Genesis 18:17-33 aangetref. Weer is daar sprake van 'n outeur wat sekere gedeeltes saamvoeg. Maar die wyse waarop dit gebeur het, "is an act of narrative composition". Alles is dus kunstig saamgevoeg "(and) not a mere pasting of differing narrative sections on top of each other" 52 . Vanuit sy tipiese estetiese waardering vir die teks word die outeur vir Loader 'n besondere kunstenaar ${ }^{53}$. Weer wil ek verklaar dat hierdie soort "immanente" omgaan met die teks en die raaksien van elke klein teksdetail ' $n$ buitengewone kragpunt in die Loaderoeuvre is. 'n Mens kan dit inderdaad as kundig en wetenskaplik, fris en oorspronklik, kunsryk en kreatief beskou. Met die beste wil ter wêreld kan ek egter nie begryp hoe dit tot historiese arbeid kan aanleiding gee nie. Ons weet mos sedert Wellhausen dat hierdie mooi en netjies finale teks histories net nie te vertroue is nie. As 'n mens dan histories met die kunstig saamgestelde en goedgestruktureerde finale teks moet omgaan, moet dit ongelukkig op sy nate oopgebreek en in bronne gedwing word. Dit klink verskriklik, maar hoe anders.

'n Mens kry die indruk dat 'n Traditionsgeschichtliche ondersoek vir Loader basies om datering gaan. Sy dateringe is buitengewoon vaag en onbevredigend. Wat hy op 'n stadium van Westermann sê, is ook op hom van toepassing: "(it) is not nuanced enough and lack depth" 54 . Aangaande Genesis 18:17-33 word sondermeer gesê "(i)t seems quite possible to think in terms of the eigth century" 55; van Psalm 78 word gesê "(it) was obviously written after the fall of Samaria" 56. Onbevredigend is die manier waarop oor "proto-deuteronomic ideas" asook "(the) deuteronomic thought" gepraat word. En die wyse waarop oor die val van Samaria en die nadenke oor die geregtigheid van God vertel word, is te maklik (hy verwys basies na 'n werk van Albright in 1955). Verder is dit ook nie seker waarom Esegiël 18 as 'n teks uit die agste en sewende eeue beskou moet word nie ${ }^{57}$. Genesis 18:17-33 se ontstaan "in late pre-exilic times" 58 , die bewering dat die Sodomsiklus "comes from a time later than the Judges passage (Judges 19:15-25)" en die tipering van Genesis 19:1-26 as "(a) seventh century story that we have before us" 59 word hoegenaamd nie begrond nie. Hoe 'n antistadsgevoel op "a pre-exilic time" 60 kan dui en die sosiale konflik 
tussen Abraham en die Sodomiete net in die monargie kon ontwikkel het $^{61}$, is werklik nie duidelik nie. In Loader se teks wemel dit van daterings wat vir hom logies en helder is, maar vir die leser verwarrend voorkom ${ }^{62}$. Nêrens word die kriteria vir die daterings nader toegelig nie. Dit is net 'n opeenstapeling van datums terwyl die doel en funksie daarvan nie so klinkklaar is nie. 'n Blote rondgooi van datums maak 'n werk ook nie sondermeer histories nie. Trouens, dit bevestig eerder die bogenoemde addendum-karakter van historiese inligting.

* By die daterings hou alles dan ook op. Met 'n blokkieskets word die vermeende groei van Genesis 18-19 saamgevat en dan is alles verby63. Volgens my moes die Traditionsgeschichtliche-studie nou eers begin het. Hierin kon die resultate van die Pentateugnavorsing handig te pas gekom het, maar Loader het hierdie insigte geïgnoreer. Oor die jare heen het geleerdes tog name vir die verskillende blokkies ${ }^{64}$ gegee en is gepoog om moontlike lewenswêrelde daarvoor oop te breek. Dít is die soort inligting wat vir 'n Traditionsgeschichtliche ondersoek onontbeerlik is.

Hierdie voorbeelde kan vermenigvuldig word, maar een ding is duidelik: dit is die een en dieselfde Loader wat ons hier teëkom. Toegegee, dinge is anders geformuleer, maar tog is dit ook nie. Voelbaar is die ou spanning tussen finaleteksstudie en geskiedenis. Steeds dien die teks-soos-hy-daar-lê as beginpunt; 'n historiese komponent is nodig, maar is nog steeds die uitvloeisel van 'n "immanente lees". 'n "Close reading" (dit is 'n struktuuranalise) van die teks-soos-hy-daar-lê "verskaf" nog steeds historiese inligting; die beweging is nog steeds van 'n struktuuranalise na die Traditionsgeschichte en die Wirkungsgeschichte. Alles lyk my nog steeds dieselfde. En ek bely my onvermoë om te sien wat werklik verander het.

'N BAIE PERSOONLIKE SLOTWOORD

Volgens Loader het ek in gebreke gebly om aan te toon of die beoefening van die Ou-Testamentiese wetenskap in Suid-Afrika werklik 'n verskil gemaak het. Instemmend haal hy Whitehead aan wat gesê het "die betekenis van bestaan is 'to make a difference"'. Hierdie norm gaan ek vir eers net op Loader van toepassing maak: Het hy 'n verskil gemaak? Kan dié verskil binnelands en buitelands geregistreer word? Het hy nuwe grond in die vak gebreek? Was sy bedrywighede nie maar die ene pedanterie nie? 
Op hierdie vrae kan ek nie 'n onvoorwaardelike antwoord verstrek nie. Miskien moet ons dit ook maar aan 'n latere geslag oorlaat om daaroor te besluit.

Ons kan egter ook anders oor ons Ou-Testamentiese verlede praat. In Story is daar juis 'n poging aangewend om dit te doen. Met behulp van 'n aantal filosowe, wat speels aangewend word, sal ek hierdie punt probeer verwoord.

a. Plato het die oorsprong van die filosofie in verwondering gesoek ${ }^{65}$. Met 'n soortgelyke verwondering is Story geskryf. Dit wat Ou-Testamentici die afgelope dertig jaar onder moeilike omstandighede verrig het, het my aangegryp en met verwondering vervul. Vandaar die "oordadige lofprysings" wat Loader tog so irriteer.

b. Volgens Karl Jaspers was die doel van enige filosofie Existenzerhellung66: die verstaan, die opheldering van menswees. Hopelik kan Story ook so 'n funksie vervul: die opheldering van ons teologiese eksistensie. Studente kan dit bestudeer en iets van ons teologiese landskap leer ken; vakgenote kan dit gebruik om hulle plek op die kaart te ontdek; buitelanders kan dit lees en iets van ons wetenskapsgeskiedenis verstaan.

c. H W Rossouw het gesê wetenskap is ook 'n kultuurhandeling67. So was ons Ou-Testamentiese wetenskapsbedryf van die afgelope jare ook 'n bepaalde kultuuronderneming. En Story wou iets, net iets, van hierdie kultuurbedryf vertel. Daarin word tog iets van ons gesê: ons tipiese vorm van eksegese, ons sterk teoretiese besinning, ons vaste teksgrepe, ons bepaalde teksteorie, ensovoorts.

d. Rossouw sê nog iets belangriks: wetenskapsbeoefening het ook met lewensin te make ${ }^{68}$. As Story maar net iets hiervan reflekteer, sal dit die skrywer tot groot blydskap stem. Geslagte lank het Suid-Afrikaanse OuTestamentici onder moeilike en geïsoleerde omstandighede getrag om deur middel van die Ou-Testamentiese wetenskap sin te maak van ons geloof en sin te gee aan die tekste wat ons lees. Uiteraard het ons dit op ons eie manier gedoen en dalk kan "ons historikus" se arbeid 'n bietjie lig werp hierop.

e. Toegegee dit is 'n baie subjektiewe geskiedenis. Karl Jaspers help my gelukkig weer deur sy beklemtoning van eerstepersoonservaringe ${ }^{69}$. Dít vorm die boustene van 'n filosofie. So is dit ook met Story gesteld: dit is 
op eie ervaringe van meer as vyf en twintig jaar gegrond en is verder 'n poging om intellektueel rekenskap van 'n spesifieke periode in ons teologiegeskiedenis te gee - 'n era wat ek bevoorreg was om mee te maak.

\section{NOTAS:}

1 J A Loader, "Die weg van die Here in die woestyn oftewel God se grootpad in die wildernis: Oor 'A Story of two Ways'”, Skrif en Kerk 15/2 (1994), 391-413.

Le Roux, A story of two ways, Pretoria 1993.

3. Loader, Skrif en Kerk 15/2 (1994), 393.

$4 \quad$ Loader, $a w, 394$.

$5 \quad$ Loader, $a w, 406$.

$6 \quad$ Loader, $a w, 406$.

$7 \quad$ Loader, $a w, 393,395,397,406,407,408$.

$8 \quad$ Loader, $a w, 402$.

$9 \quad$ Loader, $a w, 406,407-409$.

$10 \quad$ Loader, $a w, 396,398,402,404,405,407,409$.

$11 \quad$ Loader, a w, 396,402,403-409.

$12 \quad$ Loader, $a w, 408$.

$13 \quad$ Loader, $a w, 392,400,406,407$.

$14 \quad$ Loader, $a w, 402-403$.

$15 \quad$ Loader, $a w, 403,404,405$.

16 J P H Wessels, Die agtergeblewe nasies in die land. 'n Teologiese ondersoek in Rigters 2:20-3:6, Doktorale Proefskrif, Universiteit van Suid-Afrika, Pretoria 1993, 62-66.

17 R Pretorius, "Korrelkoel geskiedenis in glas omsluit", in: E Botha \& $\mathbf{R}$ Pretorius (reds), Samehang en sin, Kaapstad 1983, 53. 
Loader, $a w, 393$.

J A Loader, “Gedagtes oor gekontroleerde eksegese”, HTS 34 (1978), 1-40.

21 U Eco, The name of the rose, London 1994.

22 D Misgeld \& G Nicholson, Hans-Georg Gadamer on education, poetry, and history, New York 1992, 64.

D J Opperman, Digters van dertig, Kaapstad sj.

J C Kannemeyer, Geskiedenis van die Afrikaanse literatuur, Kaapstad 1978.

J A Loader, A tale of two cities, Kampen 1990.

Le Roux, A story of two ways, Pretoria 1993, 34-63, veral 55-57.

Le Roux, $a w, 325$.

Loader, Skrif en Kerk 15/2 (1994), 396-397.

J A Loader, Polar structures in the book of Qohelet, Berlin 1979, 1,2,3.

$30 \quad$ Loader, Skrif en Kerk 15/2 (1994), 397.

$31 \mathrm{~J}$ A Loader, Aspekte van menslike mag in die Ou Testament, Groningen 1975, 22.

32 Loader, Skrif en Kerk 15/2 (1994), 404-405.

$33 \quad$ Loader, Tale, 11.

$34 \quad$ Loader, Tale, 13.

$35 \quad$ Loader, Tale, 12.

$36 \quad$ Loader, Tale, 13.

37 Loader, Tale, 15.

$38 \quad$ Loader, Tale, 15.

39 Loader, Tale, 15,20.

40 Loader, Tale, $25,27,34,35,41,42,44,45,46$. 
Loader, Tale, 25,28.

42

Loader, Tale, 15.

43

Loader, Tale, 29,35,36,37.

44

Loader, Tale, 16,17.

45

Loader, Tale, 19,27,46.

46

Loader, Tale, 19,20,21,22,40,41.

47

Loader, Tale, 17,29,34,42,47.

48

Loader, Skrif en Kerk 15/2 (1994), 404.

49

Loader, Tale, 21.

50

Loader, Tale, 24.

51

Loader, Tale, 25-26.

52

Loader, Tale, 29,34.

53

Loader, Tale, 47.

54

Loader, Tale, 34.

55

Loader, Tale, 31.

56

Loader, Tale, 31 .

57

Loader, Tale, 32.

58

Loader, Tale, 34.

59

Loader, Tale, 42.

60

Loader, Tale, 38.

61

Loader, Tale, 43.

62

Loader, Tale, 51,52,53,54,55,58,59,60ev.

63

Loader, Tale, 46-48.

64

Loader, Tale, 48. 
65 K Jaspers, Was ist Philosophie?, München 1980, 33-34.

66 K Jaspers, Philosophie I, Berlin 1956, 1.

67 H W Rossouw, Universiteit, wetenskap en kultuur, Kaapstad 1993, 90-108.

68 Rossouw, $a w, 86-89$.

$69 \quad$ K Jaspers, $a w, 1980,39-45$. 